\title{
Absolute configuration of NFAT-133, an aromatic polyketide with immunosuppressive and antidiabetic activity from actinomycetes
}

\author{
Yanan Yang ${ }^{1}$, Linkai Yu ${ }^{1,2}$, Hisayuki Komaki ${ }^{3}$, Naoya Oku ${ }^{1}$ and Yasuhiro Igarashi ${ }^{1}$ \\ The Journal of Antibiotics (2016) 69, 69-71; doi:10.1038/ja.2015.80; published online 19 August 2015
}

NFAT-133 (1) is a relatively small, aromatic polyketide isolated from actinomycete strains of the genera Dactylosporangium ${ }^{1}$ and Streptomyces (Figure 1). ${ }^{2}$ This trialkyl-substituted benzene derivative bears three contiguous stereocenters comprising hydroxy and methyl substitutions on an alkyl side chain but the relative and absolute configurations remain unknown. NFAT-133 (1) is a pharmaceutically interesting molecule with immunosuppressive and antidiabetic activity. It inhibits transcription mediated by NFAT (nuclear factor of activated $\mathrm{T}$ cells), leading to the suppression of IL-2 (interleukin-2) expression and the following $\mathrm{T}$ cell proliferation. ${ }^{1}$ In addition, this compound stimulates glucose uptake in skeletal muscle cells. In vivo experiments with $d b / d b$ mice demonstrated its efficacy of lowering plasma glucose and insulin, without body weight gaining, ${ }^{2}$ which is a side effect of currently used thiazolidine-class antidiabetic drugs (In Kulkarni-Almeida et al., ${ }^{2}$ the structure of NFAT-133 is incorrectly presented with respect to the $\mathrm{C} 2 / \mathrm{C} 3$ double bond). In order to explore the biological potency of chemically modified derivatives of NFAT-133 (1), it became necessary to assign its absolute configuration.

In our ongoing program on chemical investigation of secondary metabolite diversity in Streptomyces species, ${ }^{3-5}$ production of 1 was noticed in the culture extract of Streptomyces karnatakensis NBRC 13051. This strain was grown in liquid medium and several steps of purification from the culture extract afforded $\mathbf{1}$ in a pure form. ${ }^{1} \mathrm{H}$ and ${ }^{13} \mathrm{C}$ NMR spectral data of $\mathbf{1}$ from strain NBRC 13051 were identical with those previously reported for NFAT-133 (Table 1). ${ }^{1,2}$

Stereochemical analysis was started with the application of chiral anisotropy method ${ }^{6}$ to the secondary hydroxy group at C11. Esterification of $\mathbf{1}$ by treatment with $(S)$ - and (R)-MTPACl gave bis- $(R)$ - and (S)-MTPA esters (2a and $\mathbf{2 b}$ ), respectively. The $\Delta \delta_{S-R}$ values were calculated by subtracting the ${ }^{1} \mathrm{H}$ NMR chemical shifts $\delta_{\mathrm{H}}$ of $\mathbf{2} \mathbf{a}$ from that of $\mathbf{2} \mathbf{b}$. Although the $\Delta \delta_{S-R}$ values were zero for H12 and $\mathrm{H} 17$, a positive value was observed for $\mathrm{H} 14$ and negative values were observed for $\mathrm{H} 2, \mathrm{H} 3, \mathrm{H} 10$ and $\mathrm{H}_{16}{ }^{6}$ The absolute configuration at $\mathrm{C} 11$ was thus determined as $R$. The relative configuration at $\mathrm{C} 10$ and $\mathrm{C} 12$ was deduced from the analysis of the coupling constants. The large ${ }^{3} J_{\mathrm{H} 10, \mathrm{H} 11}(7.0 \mathrm{~Hz})$ and the small ${ }^{3} J_{\mathrm{H} 11, \mathrm{H} 12}$ values $(3.9 \mathrm{~Hz})$ indicated the anti and syn relationships for $\mathrm{H} 10 / \mathrm{H} 11$ and $\mathrm{H} 11 / \mathrm{H} 12$, respectively (Figure 2). This assignment was in good agreement with the NOEs observed between $\mathrm{H} 10$ and $\mathrm{H} 17$ and between $\mathrm{H} 12$ and $\mathrm{H} 16$ in the NOESY spectrum (Figure 3). Furthermore, NOEs between H3 and $\mathrm{H} 10, \mathrm{H} 8$ and $\mathrm{H} 11$, and $\mathrm{H} 2$ and $\mathrm{H} 5$ suggested that the side chains at $\mathrm{C} 4$ and $\mathrm{C} 9$ were extending from the aromatic core to set apart from each other (Figure 3). To further validate the stereochemical assignment, J-based configuration analysis ${ }^{7}$ was employed for the rotamers around $\mathrm{C} 10-\mathrm{C} 11$ and $\mathrm{C} 11-\mathrm{C} 12$ axes. Heteronuclear long-range coupling constants ${ }^{2} J_{\mathrm{CH}}$ were determined to be $5.6 \mathrm{~Hz}$ for $\mathrm{H} 10 / \mathrm{Cl1}$ and $2.3 \mathrm{~Hz}$ for $\mathrm{H} 12 / \mathrm{C} 11$ by $J-\mathrm{HMBC}$ experiment. ${ }^{8}$ These values established the gauche relationship for $\mathrm{H} 10$ and $11-\mathrm{OH}$ and the anti relationship for $\mathrm{H} 12$ and $11-\mathrm{OH}$ (Figure 4), consistent with the results from the NOESY experiment and configuration analysis based on ${ }^{3} J_{\mathrm{HH}}$ coupling values.

On the basis of these spectroscopic evidences, the asymmetric centers present in 1 were determined to have $10 R, 11 R$ and $12 S$ configurations. This stereochemical information will facilitate the structure-activity relationship study for evaluation of $\mathbf{1}$ as a lead scaffold for the immunosuppressive or antidiabetic agent.

\section{EXPERIMENTAL SECTION}

General

Optical rotation was measured using a JASCO DIP-3000 polarimeter. UV spectrum was recorded on a Hitachi U-3210 spectrophotometer (Hitachi-High-Technologies Co., Tokyo, Japan). IR spectrum was measured on a PerkinElmer Spectrum 100. NMR spectra were obtained on a Bruker AVANCE 500 spectrometer (Bruker Biospin K. K., Yokohama, Japan). High resolution ESITOFMS were recorded on a Bruker micrOTOF focus (Bruker Daltonics K. K., Yokohama, Japan).

\footnotetext{
${ }^{1}$ Biotechnology Research Center and Department of Biotechnology, Toyama Prefectural University, Toyama, Japan; ${ }^{2}$ School of Biological and Chemical Engineering, Zhejiang University of Science and Technology, Hangzhou, China and ${ }^{3}$ Biological Resource Center, National Institute of Technology and Evaluation (NBRC), Chiba, Japan Correspondence: Professor Y Igarashi, Biotechnology Research Center and Department of Biotechnology, Toyama Prefectural University, 5180 Kurokawa, Imizu 939-0398, Toyama, Japan.

E-mail: yas@pu-toyama.ac.jp

Received 5 February 2015; revised 7 May 2015; accepted 14 May 2015; published online 19 August 2015
} 
<smiles>CC(=O)[C@H](C)[C@@H](O)[C@@H](C)c1ccc(C)cc1/C=C/CO</smiles>

Figure 1 Absolute configuration of NFAT-133 (1).

Table 1 NMR data for NFAT-133 (1)

\begin{tabular}{|c|c|c|c|c|}
\hline \multirow{2}{*}{ Position } & \multicolumn{2}{|l|}{$C D_{3} O D^{\mathrm{a}}$} & \multicolumn{2}{|l|}{$\mathrm{CDCl}_{3}^{\mathrm{b}}$} \\
\hline & $\delta_{H}$ mult $(\mathrm{J}$ in $\mathrm{Hz})$ & $\delta_{C}$ & $\delta_{H}(m u l t, J$ in $\mathrm{Hz})$ & $\delta_{C}$ \\
\hline 1 & $4.28 \mathrm{dd}(5.4,1.4)$ & 63.7 & $4.35 \mathrm{~d}(5.4)$ & 63.7 \\
\hline 2 & $6.18 \mathrm{dt}(15.6,5.4)$ & 132.8 & $6.19 \mathrm{dt}(15.6,5.4)$ & 131.5 \\
\hline 3 & $6.97 \mathrm{~d}(15.6)$ & 129.3 & $6.93 \mathrm{~d}(15.6)$ & 128.8 \\
\hline 4 & & 137.1 & & 136.0 \\
\hline 5 & $7.27 \mathrm{~s}$ & 128.6 & $7.24 \mathrm{~s}$ & 127.9 \\
\hline 6 & & 137.0 & & 135.8 \\
\hline 7 & $7.09 \mathrm{~d}(8.0)$ & 129.7 & $7.05 \mathrm{~d}(8.0)$ & 128.6 \\
\hline 8 & $7.17 \mathrm{~d}(8.0)$ & 128.0 & $7.07 \mathrm{~d}(8.0)$ & 126.5 \\
\hline 9 & & 140.2 & & 138.5 \\
\hline 10 & $3.11 \mathrm{dq}(9.0,6.9)$ & 39.7 & $3.11 \mathrm{dq}(7.8,6.9)$ & 37.3 \\
\hline 11 & $4.24 \mathrm{dd}(9.0,3.6)$ & 76.6 & $4.11 \mathrm{dd}(7.8,4.0)$ & 74.6 \\
\hline 12 & $2.38 \mathrm{dq}(3.6,7.0)$ & 51.2 & $2.48 \mathrm{dq}(4.0,7.2)$ & 48.5 \\
\hline 13 & & 214.1 & & 214.2 \\
\hline 14 & $2.07 \mathrm{~s}$ & 28.4 & $2.13 \mathrm{~s}$ & 29.3 \\
\hline 15 & $2.30 \mathrm{~s}$ & 21.0 & $2.33 \mathrm{~s}$ & 21.0 \\
\hline 16 & $1.32 \mathrm{~d}(6.9)$ & 19.3 & $1.32 \mathrm{~d}(6.9)$ & 17.5 \\
\hline 17 & $0.97 d(7.0)$ & 9.6 & $1.08 \mathrm{~d}(7.2)$ & 10.7 \\
\hline
\end{tabular}

aReferenced to $\delta_{\mathrm{H}} 3.31$ and $\delta_{\mathrm{C}} 49.0$.

bReferenced to $\delta_{H} 7.27$ and $\delta_{C} 77.0$

\section{Fermentation and isolation}

Streptomyces karnatakensis NBRC 13051 was obtained from Biological Resource Center, National Institute of Technology and Evaluation, Chiba, Japan. Strain NBRC 13051 cultured on a slant agar medium was inoculated into $500-\mathrm{ml} \mathrm{K}-1$ flasks each containing $100 \mathrm{ml}$ of the $\mathrm{V}-22$ seed medium consisting of soluble starch $1 \%$, glucose $0.5 \%$, NZ-case $0.3 \%$, yeast extract $0.2 \%$, Tryptone (Difco Laboratories, Sparks, MD, USA) $0.5 \%, \mathrm{~K}_{2} \mathrm{HPO}_{4} \quad 0.1 \%, \mathrm{MgSO}_{4} \cdot 7 \mathrm{H}_{2} \mathrm{O} \quad 0.05 \%$, and $\mathrm{CaCO}_{3} 0.3 \%(\mathrm{pH} 7.0)$. The flasks were placed on a rotary shaker (200 r.p.m.) at $30^{\circ} \mathrm{C}$ for 4 days. The seed culture $(3 \mathrm{ml})$ was transferred into $500-\mathrm{ml} \mathrm{K}-1$ flasks each containing $100 \mathrm{ml}$ of the A-3M production medium consisting of glucose $0.5 \%$, Pharmamedia (Traders Protein, Memphis, TN, USA) $1.5 \%, \mathrm{CaCO}_{3} \mathrm{0.5} \%$, and Diaion HP-20 (Mitsubishi Chemical, Kanagawa, Japan) 1.0\%. The $\mathrm{pH}$ of the medium was adjusted to 7.0 before sterilization. The inoculated flasks were cultured on a rotary shaker $(200$ r.p.m. $)$ at $30^{\circ} \mathrm{C}$ for 6 days.

At the end of the fermentation period, $50 \mathrm{ml}$ of 1-butanol were added to each flask, and they were allowed to shake for $1 \mathrm{~h}$. The mixture was centrifuged at 6000 r.p.m. for $10 \mathrm{~min}$ and the organic layer was separated from the aqueous layer containing the mycelium. Evaporation of the solvent gave $5.55 \mathrm{~g}$ of extract from 21 of culture. The crude extract $(5.55 \mathrm{~g})$ was subjected to silica gel column

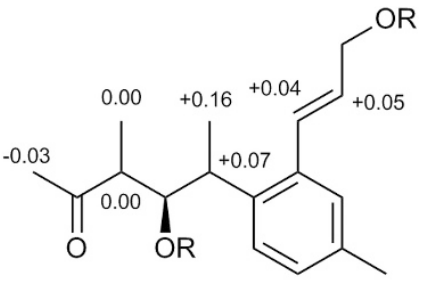

2a $: \mathrm{R}=(R)-\mathrm{MTPA}$

$\mathbf{2 b}: \mathbf{R}=(S)-M T P A$

Figure $2 \Delta \delta_{S-R}$ values for MTPA esters (2a) and (2b) of 1 .

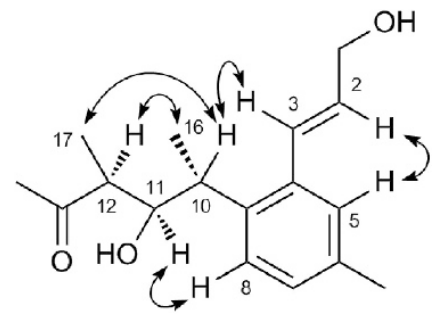

Figure 3 Key NOESY correlations for 1 .

a<smiles>[GeH3]</smiles>

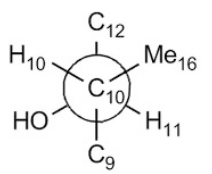

${ }^{3} J(\mathrm{H} 10, \mathrm{H} 11)=7.0 \mathrm{~Hz}$

$2 J(\mathrm{C} 11, \mathrm{H} 10)=5.6 \mathrm{~Hz}^{*}$

Figure 4 Configuration analysis for $\mathrm{C} 10-\mathrm{C} 12$ based on the coupling constants for $1 .{ }^{*}$ Indicates absolute values.

chromatography with a step gradient of $\mathrm{CHCl}_{3}-\mathrm{MeOH}(1: 0,20: 1,10: 1$, $4: 1,2: 1,1: 1$ and $0: 1 \mathrm{v} / \mathrm{v})$. The fourth fraction (4:1) was concentrated to provide $2.25 \mathrm{~g}$ of brownish oil, a portion $(374 \mathrm{mg}$ ) of which was further separated by reversed-phase ODS column chromatography with a gradient of $\mathrm{MeCN}-0.1 \% \mathrm{HCO}_{2} \mathrm{H}$ solution (2:8, 3:7, 4:6, 5:5, 6:4, $7: 3$ and $8: 2 \mathrm{v} / \mathrm{v})$. The fourth fraction (5:5) was evaporated and extracted with EtOAc. The organic layer was concentrated to afford 1 (61 mg).

NFAT-133 (1): pale yellow oil; $[\alpha]^{22} \mathrm{D}+24$ (c $\left.0.45, \mathrm{MeOH}\right)$; UV (MeOH) $\lambda_{\max }(\log \varepsilon) 213$ (4.95), 247 (4.59) nm; IR (ATR) $\nu_{\max } 3364,2969,2932,1699 \mathrm{~cm}^{-1}$; HR-ESITOFMS $[\mathrm{M}+\mathrm{Na}]^{+}$ 299.1610 (calcd for $\mathrm{C}_{17} \mathrm{H}_{24} \mathrm{O}_{3} \mathrm{Na}, 299.1618$ ).

Bis-(R)-MTPA ester of $\mathbf{1}(\mathbf{2 a})$. To a solution of $\mathbf{1}(0.5 \mathrm{mg}, 1.8 \mu \mathrm{mol})$ in dry pyridine $(100 \mu \mathrm{l})$ was added $(S)$-MTPA chrolide $(7 \mu \mathrm{l}, 37 \mu \mathrm{mol})$ at room temperature. After standing for $1 \mathrm{~h}$, the reaction mixture was concentrated under reduced pressure, and the residue was purified by silica gel column chromatography $(n$-hexane/EtOAc $=8: 1 \sim 1: 1)$ to give bis- $(R)$-MTPA ester $\mathbf{2 a}(0.6 \mathrm{mg}, 46 \%$ yield $):{ }^{1} \mathrm{H}$ NMR $(500 \mathrm{MHz}$, $\left.\mathrm{CDCl}_{3}\right) \delta 0.93(3 \mathrm{H}, \mathrm{d}, J=7.0 \mathrm{~Hz}, \mathrm{H}-17), 1.06(3 \mathrm{H}, \mathrm{d}, J=6.9 \mathrm{~Hz}$, H-16), 2.09 (3H, s, H-14), 2.34 (3H, s, H-15), 2.44 (1H, dq, $J=2.6$, $7.0 \mathrm{~Hz}, \mathrm{H}-12), 3.25$ (1H, dq, $J=9.7,6.9 \mathrm{~Hz}, \mathrm{H}-10), 4.99$ (2H, m, H-1), 
$5.83(1 \mathrm{H}, \mathrm{dd}, J=9.7,2.6 \mathrm{~Hz}, \mathrm{H}-11), 6.12(1 \mathrm{H}, \mathrm{dt}, J=15.6,6.3 \mathrm{~Hz}$, $\mathrm{H}-2), 7.00(1 \mathrm{H}, \mathrm{d}, J=15.6 \mathrm{~Hz}, \mathrm{H}-3)$; HR-ESITOFMS $m / z 731.2414$ $[\mathrm{M}+\mathrm{Na}]^{+}$(calcd for $\mathrm{C}_{37} \mathrm{H}_{38} \mathrm{~F}_{6} \mathrm{O}_{7} \mathrm{Na} 731.2414$ ).

Bis-(S)-MTPA ester of $\mathbf{1}(\mathbf{2 b})$. In the same manner as described for 2a, 2b (0.4 mg, 32\%) was prepared from $1(0.5 \mathrm{mg}, 1.8 \mu \mathrm{mol})$ and (R)-MTPA chrolide: ${ }^{1} \mathrm{H}$ NMR $\left(500 \mathrm{MHz}, \mathrm{CDCl}_{3}\right) \delta 0.93(3 \mathrm{H}, \mathrm{d}$, $J=7.0 \mathrm{~Hz}, \mathrm{H}-17), 1.23(3 \mathrm{H}, \mathrm{d}, J=6.9 \mathrm{~Hz}, \mathrm{H}-16), 2.06(3 \mathrm{H}, \mathrm{s}, \mathrm{H}-14)$, $2.35(3 \mathrm{H}, \mathrm{s}, \mathrm{H}-15), 2.44(1 \mathrm{H}, \mathrm{dq}, J=2.9,7.0 \mathrm{~Hz}, \mathrm{H}-12), 3.32(1 \mathrm{H}, \mathrm{dq}$, $J=9.4,6.9 \mathrm{~Hz}, \mathrm{H}-10), 5.02(2 \mathrm{H}, \mathrm{m}, \mathrm{H}-1), 5.83(1 \mathrm{H}, \mathrm{dd}, J=9.4,2.9 \mathrm{~Hz}$, $\mathrm{H}-11), 6.15(1 \mathrm{H}, \mathrm{dt}, J=15.6,6.2 \mathrm{~Hz}, \mathrm{H}-2), 7.05(1 \mathrm{H}, \mathrm{d}, J=15.6 \mathrm{~Hz}$, $\mathrm{H}-3) ; \quad$ HR-ESITOFMS $\mathrm{m} / \mathrm{z} \quad 731.2414 \quad[\mathrm{M}+\mathrm{Na}]^{+}$(calcd for $\left.\mathrm{C}_{37} \mathrm{H}_{38} \mathrm{~F}_{6} \mathrm{O}_{7} \mathrm{Na} 731.2414\right)$.

\section{CONFLICT OF INTEREST}

The authors declare no conflict of interest.
1 Burres, N. S. et al. Simple aromatics identified with a NFAT-lacZ transcription assay for the detection of immunosuppressants. J. Antibiot. 48, 380-386 (1995).

2 Kulkarni-Almeida, A. A. et al. Fermentation, isolation, structure, and antidiabetic activity of NFAT-133 produced by Streptomyces strain PM0324667. AMB Express 1, 42 (2011).

3 Igarashi, Y. et al. Alchivemycin A, a bioactive polycyclic polyketide with an unprecedented skeleton from Streptomyces sp. Org. Lett. 12, 3402-3405 (2010).

4 Igarashi, Y. et al. Akaeolide, a carbocyclic polyketide from marine-derived Streptomyces. Org. Lett. 15, 5678-5681 (2013).

5 Igarashi, $Y$. et al. Jomthonic acid $A$, a modified amino acid from a soil-derived Streptomyces. J. Nat. Prod. 75, 986-990 (2012).

6 Seco, J. M., Quiñoá, E. \& Riguera, R. The assignment of absolute configuration by NMR. Chem. Rev. 104, 17-117 (2004).

7 Matsumori, N., Kaneno, D., Murata, M., Nakamura, H. \& Tachibana, K. Stereochemical determination of acyclic structures based on carbon-proton spin-coupling constants. A method of configuration analysis for natural products. J. Org. Chem. 64 866-876 (1999).

8 Meissner, A. \& Sørensen, W. Measurement of $J(H, H)$ and long-range $J(X, H)$ coupling constants in small molecules. Broadband XLOC and J-HMBC. Magn. Reson. Chem. 39, 49-52 (2001).

Supplementary Information accompanies the paper on The Journal of Antibiotics website (http://www.nature.com/ja) 